Oliver Budzinski \& Katalin Monostori:

Intellectual property rights and the WTO:

innovation dynamics, commercial copyrights and international governance

Original published in:

International Law Research, 1 (2012), 1, p.102-118.

ISSN (Online): 1927-5242

DOI:10.5539/ilr.v1n1p102

URL: http://dx.doi.org/10.5539/ilr.v1n1p102

(Stand: 21.01.2013)

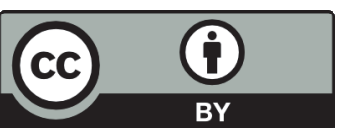

This work is licensed under a Creative Commons Attribution 3.0 Unported License.

[http://creativecommons.org/licenses/by/3.0/] 


\title{
Intellectual Property Rights and the WTO: Innovation Dynamics, Commercial Copyrights and International Governance
}

\author{
Oliver Budzinski ${ }^{1} \&$ Katalin Monostori ${ }^{2}$ \\ ${ }^{1}$ Economic Theory, Ilmenau University of Technology, Ilmenau, Germany \\ ${ }^{2}$ Markets \& Competition Group, Department of Environmental and Business Economics, University of Southern \\ Denmark, Esbjerg, Denmark \\ Correspondence: Oliver Budzinski, Economic Theory, Ilmenau University of Technology, Ilmenau, Germany. \\ Tel: 49-367-769-4030. E-mail: oliver.budzinski@tu-ilmenau.de
}

Received: September 23, 2012 Accepted: October 11, $2012 \quad$ Online Published: October 26, 2012

doi:10.5539/ilr.v1n1p102 URL: http://dx.doi.org/10.5539/ilr.v1n1p102

\begin{abstract}
In the context of the WTO, intellectual property rights (IPR) are codified in the TRIPS-agreement. While covering all the different types of IPR, landmark cases of the still young history of TRIPS have dealt with commercial copyrights. This paper summarizes the basic economics of the IPR branch commercial copyrights, reviews the TRIPS history and analyses two TRIPS landmark cases - China-IPR and US-copyrights - from an economic perspective. Eventually, the paper outlines new challenges for the international governance of IPR in the WTO context emerging from digital media. Against an economic background, the re-emergence of unilateral strategies to enforce cross-border commercial copyrights is met with skepticism against.
\end{abstract}

Keywords: intellectual property rights, TRIPS, world trade, commercial copyrights, media economics, innovation

JEL: O34, F02, F13, L82, D02, B52

\section{Introduction}

International agreements and regulations of intellectual property rights (IPR) are on the agenda of the world economic order since the $19^{\text {th }}$ century. Thus, not only have IPR been viewed to constitute a cross-border economic problem that is closely related to trading goods, actually it has been viewed to represent a relevant problem for international economic governance on its own merits very quickly and early. At the same time, the design and shaping of international rules of IPR have always been very controversial and consensus appeared to be impossible for a long time - and in a way this has not changed to this day. As one of the consequences, a multitude of forums dealing with international cooperation (of differing degrees) on IPR has emerged and partly disappeared again. Often, a new agenda was accompanied by establishing a new forum. Arguably the most powerful international initiative was put forward in the context of founding and establishing the World Trade Organization (WTO) in 1995. One of its - more controversial, however - pillars is the so-called TRIPS-agreement, covering Trade-Related Intellectual Property Rights.

However, the - political as well as academic - debate on IPR has always not only been shaped by different opinions and interests of different players in different countries. In fact, the innovation dynamics of media markets, i.e. markets for information storage and transmission, have generated a dynamic evolution of the economic problems of cross-border IP trade and effects as well. From a focus on written media in the $19^{\text {th }}$ century via the emergence of radio and television during the $20^{\text {th }}$ century until the era of the internet and digitalized information towards the end of the $20^{\text {th }}$ century and during the still young $21^{\text {st }}$ century, the economic forces of dealing with media-codified IP have been subject to constant change, thereby, putting up frequent challenges to existing rules and practices. International governance appropriate to the written era may not fit with over-the-air broadcasting and the worldwide internet with digitalized content may render many of those rules obsolete once again. This is also true for TRIPS, which basically is rooted in the pre-digitalized and pre-internet era.

IP fundamentally is about information and knowledge, which is stored and transmitted via media. Still, the economics of IP differ considerably depending on what kind of IP is analyzed. Technological innovation codified 
in patents, for instance, represent different challenges from less-formally codified business secrets or commercial copyrights. Since it is virtually impossible to address all the different dimensions of IPR in such a brief paper and since commercial copyrights are more prone to the challenges of innovation dynamics through digitalization and, at the same time, have triggered some of the core WTO-TRIPS cases so far, this paper focuses on the international governance of commercial copyrights in the context of WTO TRIPS-agreement (sections 3 and 4) as well as new challenges to this governance (section 5). Section 2 starts with summarizing some basic economics of IPR and commercial copyrights, section 6 concludes.

\section{Some Basic Economics of Intellectual Property Rights and Commercial Copyrights}

Intellectual property rights (IPR) are an institutional construct that serves to create exclusive and individual property rights for defined creations of mind, namely intangible assets such as (i) literary, musical and artistic creations, (ii) inventions, as well as (iii and iv) phrases, symbols and designs. Property of these immaterial goods is codified by law into specified rights like (i) copyrights, (ii) patents, (iii) trademarks, and (iv) industrial design (commercial secrets) rights. Although, our review on TRIPS and its current controversies (section 3) touches upon all of these areas, our main analysis (sections 2, 4 and 5) focuses on copyrights. At the end of the day, IPR protection and copyright systems are about institutional arrangements to organize information production and dissemination.

From an economic perspective, individual and exclusive property rights on creations of mind are ambiguous regarding their effects on innovation dynamics (inter alia, Landes \& Posne,r 1989; Koboldt, 1995; Gordon \& Watt, 2003; Watt, 2004; Schmidt, 2010: 86-92; Belleflamme \& Peitz, 2012). On the one hand, strong IPR serve to internalize positive externalities (Hurt \& Schuchman, 1966). Without IPR, all these creations of mind would be free to be used for commercial purposes once they are 'out' without giving the creator any possibility to comprehensively appropriate the commercial benefits her creation brings to numerous 'exploiters'. The important difference to 'ordinary' goods is constituted by the informational character of intellectual property: once information is known by someone, it cannot be taken back anymore and its (commercial) use cannot be prevented anymore in the absence of IPR (Note 1). The economic downside of this positive externality lies in the lack of incentives to engage in intellectual creations. If a creator cannot appropriate her share of commercial benefits resting upon her creation, then the incentive for undertaking the burdens and costs of creating activities are low. Or, more precisely, the economic (monetary) incentives are dysfunctional; it is still possible that creators are motivated by intrinsic incentives that are non-economic and non-monetary by nature. However, as long as the sum of intellectual creations based on economic and intrinsic incentives is deemed to be larger than intellectual creations based on intrinsic incentives only, the conclusion holds that the absence of IPR harms innovation dynamics.

Yet, there is another side to this story. Diffusion of intellectual creations and, thus, dynamics creating innovation by using the intellectual creations as an input are hampered and slowed down by IPR. A regime of imitation liberty creates more innovation dynamics from an initial creation by encouraging follow-on creations (Watt 2004). In the economic literature, granting IPR is often viewed to constitute an (artificial) monopoly for the intellectual creation that otherwise would be free to use for everyone (Note 2). As a consequence, solving the underproduction problem due to positive externalities generates an underutilization problem due to the market power of the creator (who is granted a monopoly privilege). The (artificial) monopoly power allows the creator not only to appropriate the revenues of her creation, it furthermore allows her to set prices above marginal costs and to reap monopoly rents. This leads to welfare-reducing rationing (Yoon, 2002; Belleflamme \& Peitz, 2012).

However, from an institutional and competition economics-informed perspective, this problem is somewhat more complex. First of all, all property rights are institutional arrangements and as such social constructs. Defining property rights for information goods and creations of the mind by law is a priori neither more, nor less artificial or natural as defining property rights for any other type of (material) goods by law. Property rights always require a codified content specification, an utilization specification (including the limits to property rights) as well as commercial laws defining the trade of these goods (conveyance or transfer of property). Furthermore, implementing a court system and police forces in order to enforce the socially defined property rights is fundamental. As such, property rights for intellectual goods do not constitute a special privilege for their owners in the context of a market economy system.

More intriguing, secondly, is the question whether IPR constitute a monopoly as it is predominantly assumed in the economic literature on copyrights (overview: Belleflamme \& Peitz, 2012). It requires a rather abstract definition of a monopoly to come to this conclusion. Only if the absence of an identical product, i.e. a perfect substitute, is viewed to be a sufficient condition to constitute a monopoly, then assigning exclusive intellectual 
property rights to creations of the mind automatically and inevitably create a monopoly. The reason is that intellectual products are unique in the sense that they are not perfectly identical to other products, hence no perfect substitute exists. However, there are two relevant problems with this view. First, even if this view was accepted (for the sake of the argument), this - again - would not represent a special characteristic of creations of the mind. Quite in contrast, it would be exactly the same with any other type of good: if the produced good was unique and no perfectly identical other product existed, exclusive property right on it would always create a monopoly. However, secondly, this is not how monopolies are usually defined in competition economics. Uniqueness in the sense of the absence of perfect substitutes (i.e. identical products) must not be confused with the absence of relevant substitutes exerting competitive pressure and thus competitively disciplining the property rights holder. Monopoly power only comes into existence if no effective substitute exists, which explicitly includes imperfect substitutes! It is not the fundamental uniqueness of creations of mind that is decisive for the emergence of market power, it is the question whether similar/comparable (but not identical) products exist which serve to satisfy the same desires of the consumers and, consequently, serve as (imperfect) substitutes in the eyes of the consumers. Competition and antitrust economics have developed several techniques (including advanced and sophisticated econometric methods) to delineate a relevant market with heterogeneous goods (which exist much more widespread than homogenous markets) (inter alia, Kerber \& Schwalbe, 2008: 262-277). Thus, whether IPR create monopolies depends on the existence of (perfect and imperfect) substitutes and does not represent an automatism - just like with any 'ordinary' good. For instance, a patent on a new technology or a new active pharmaceutical substance may actually represent a monopoly and allow for monopolistic behavior of the IPR holder. However, a new song by, say, Rihanna (or her songwriters) or a new crime thriller by any popular or not-so-popular author certainly fails any standard, state-of-the-art monopoly test since it stands in direct competition with other new pop songs and other new crime stories, respectively. Even though mainstream pop songs, for instance, are not identical, they obviously represent strong substitutes to pop music consumers (Note 3). From an antitrust point of view, it would be more than strange to define a relevant market to consist of "Ai se eutepego" by Michel Telóand nothing else and, at the same time, to claim that "Heart Skips a Beat" by OllyMurs or "Forgive Forget" by Caligola (taking the top three hits from itunes as these lines are written) constitute other, separate one-product markets (Note 4). This cannot be aligned with any common economic market delineation concept. Instead, any sensible relevant market delineation will include a multitude of songs, records, books, etc. that represent imperfect but close-enough substitutes to exert competitive pressure on each other.

In other words, it requires a case-by-case analysis to conclude whether any given IPR constitutes a monopoly and in many cases this will not be the case. If a monopoly is constituted, then welfare-reducing exploitation of the related market power by the creator can be expected. Furthermore, IPR may in such cases be used to deter competition in related or neighboring markets and to leverage market power (Schmidt, 2010).

In summary, IPR promote creations but may hamper their diffusion (depending on the competitive situation). This trade-off may be alleviated (i) within the system of IPR, for instance

- by the specific design of the protective content of IPR,

- temporary protection rights (like existing patents and copyrights are typically shaped), or

- mandatory licensing of intellectual property (with regulated prices)

or (ii) by adopting some sort of imitation liberty regime and implementing an alternative compensation scheme for creators, like public alimentation (Koboldt, 1995: 22).

\section{The TRIPS Agreement}

\subsection{History and Major Content}

Coming from such a system of imitation liberty accompanied by an informal system of alimenting creators by local authorities in medieval times, the development of todays widespread IPR regimes only started during the $19^{\text {th }}$ century (despite few earlier predecessors). In many areas of intellectual property, it was quite quickly realized that this area is specifically subject to cross-border effects. Information and information flow is much more difficult to regulate at territorial borders than trade with 'ordinary' goods - and this was true even before the emergence of the worldwide web (internet). Consequently, first attempts to establish international rules on IPR date back to the late $19^{\text {th }}$ century, e.g. United International Bureaux for the Protection of Intellectual Property established 1893 in Berne and relocated to Geneva in 1960. The development took an important step in 1967 when the World Intellectual Property Organization (WIPO) succeeded the bureau as an agency of the United Nations. See Table 1 on the work and the development of WIPO. 
Table 1. History of WIPO

\begin{tabular}{|c|c|}
\hline Date & Main happenings \\
\hline 14.07.1967 & Signing of the WIPO Convention, which officially establishes WIPO \\
\hline \multirow[t]{2}{*}{1970} & WIPO comes into force \\
\hline & Patent Cooperation Treaty \\
\hline \multirow[t]{2}{*}{ 19.06.1970 } & $\begin{array}{l}\text { Provides the possibility to apply for patent protection in several member countries by filling one } \\
\text { international form }\end{array}$ \\
\hline & Strasbourg Agreement \\
\hline \multirow[t]{2}{*}{ 24.03.1971 } & $\begin{array}{l}\text { Establishes the International Patent Classification, an overall system which creates transparency by } \\
\text { systemizing the different branches of technology and providing each branch different codes }\end{array}$ \\
\hline & Phonogram Convention \\
\hline 20.10.1971 & $\begin{array}{l}\text { Provides a protection for phonogram producers in each Contracting State against the unauthorized } \\
\text { duplication of phonograms and the importation and distribution of such duplicates. }\end{array}$ \\
\hline \multirow{2}{*}{ 12.06.1973 } & Vienna Agreement \\
\hline & ication of marks, containing figurative elements \\
\hline \multirow[b]{2}{*}{ 21.05.1974 } & Brussels Convention \\
\hline & $\begin{array}{l}\text { Provides the obligation for the Contracting Parties to prevent unauthorized distribution transmitted by } \\
\text { satellite on or from its territory }\end{array}$ \\
\hline \multirow[t]{2}{*}{ 17.12.1974 } & WIPO becomes a specialized agency of the United Nations \\
\hline & Budapest Treaty \\
\hline 28.04.1977 & $\begin{array}{l}\text { Any Contracting State which allows or requires the deposit of microorganisms for patent procedures } \\
\text { must recognize this deposit with any "international depositary authority" }\end{array}$ \\
\hline \multirow[b]{2}{*}{ 26.09.1981 } & Nairobi Treaty \\
\hline & $\begin{array}{l}\text { All Contracting States have to protect the Olympic symbol against commercial purposes not } \\
\text { authorized by the International Olympic Committee }\end{array}$ \\
\hline \multirow[b]{2}{*}{ 26.05.1989 } & Washington Treaty (not yet in force) \\
\hline & $\begin{array}{l}\text { Gives Contracting Parties the obligation to secure intellectual property protection connected to } \\
\text { layout-designs (topographies) throughout their territories }\end{array}$ \\
\hline \multirow{3}{*}{ 27.06.1989 } & Protocol relating to the Madrid Agreement \\
\hline & $\begin{array}{l}\text { The Madrid Agreement (1891) makes it possible to protect a mark in several countries by obtaining an } \\
\text { international registration }\end{array}$ \\
\hline & $\begin{array}{l}\text { The Protocol aims to make the Agreement more flexible and more compatible with the national } \\
\text { legislation of countries who could not accept the Agreement itself }\end{array}$ \\
\hline \multirow[b]{2}{*}{ 27.10.1994 } & Trademark Law Treaty \\
\hline & $\begin{array}{l}\text { Aims to modernize national and regional trademark registration procedures by simplifying and } \\
\text { standardizing certain features. }\end{array}$ \\
\hline 01.01 .1996 & Cooperation Agreement between WIPO and WTO comes into force \\
\hline \multirow{5}{*}{ 20.12.1996 } & WIPO Copyright Treaty (entering into force: 06.03 .2002 ) \\
\hline & $\begin{array}{l}\text { Provides additional copyrights for works which are not protected by the Berne Convention due to the } \\
\text { development of technology (computer programs, databases) }\end{array}$ \\
\hline & Deals with wider rights of authors (right of distribution, rental and communication to the public) \\
\hline & WIPO Performances and Phonograms Treaty (entered into force 05.02.2002) \\
\hline & Grants economic and moral rights to performers and producers of phonograms \\
\hline \multirow{3}{*}{ 01.06.2000 } & Patent Law Treaty (entered into force: 28.04 .2005 ) \\
\hline & Aims to make patent procedures more 'user-friendly' \\
\hline & Provides a minimum standard which the Offices of Contracting Parties may apply \\
\hline \multirow{3}{*}{ 27.03.2006 } & Singapore Treaty on the Law of Trademarks \\
\hline & $\begin{array}{l}\text { Provides a dynamic international framework for the harmonization of trademark registration } \\
\text { procedures }\end{array}$ \\
\hline & $\begin{array}{l}\text { Compared to the Trademark Law Treaty it has a wider scope for example in communication } \\
\text { technology }\end{array}$ \\
\hline
\end{tabular}

(Source: own compilation of information from www.wipo.int)

Shortcomings regarding the binding character of WIPO provisions, the comprehensiveness of intellectual property protection, the territorial reach as well as enforcement mechanisms led to the U.S. as well as many other industrialized countries initiating IPR in the context of GATT/WTO. The Uruguay GATT round adopted the 
Trade-Related Aspects of Intellectual Property Rights (TRIPS) agreement, which became a substantial part of the new-established World Trade Organization (WTO, 1995; see Table 2).

Table 2. History of TRIPS

\begin{tabular}{|c|c|}
\hline Date & Main happenings \\
\hline 01.01.1995 & TRIPS Agreement officially comes into force (with given transitional periods for the Members) \\
\hline 01.01.1996 & TRIPS enters into force for developed countries \\
\hline $\begin{array}{l}\text { 9-3.12.1996 } \\
\text { 1st WTO Ministerial } \\
\text { Conference, Singapore }\end{array}$ & $\begin{array}{l}\text { - Decision about the monitoring of the implementation of the Agreement - developed countries } \\
\text { - Decision about the provision of financial and technical cooperation of developed countries with } \\
\text { developing and least-developed Members } \\
\text { - Decision about a review of the application of the provisions on geographical indications }\end{array}$ \\
\hline 01.01.2000 & $\begin{array}{l}\text { TRIPS enters into force for developing countries - with the possibility of prolonging the transitional } \\
\text { period with } 5 \text { years if the preparation is not ready }\end{array}$ \\
\hline $\begin{array}{l}\text { 9-14.11.2001 } \\
\text { 4th WTO Ministerial } \\
\text { Conference, Doha, Qatar }\end{array}$ & $\begin{array}{l}\text { Doha Declaration } \\
\text { - Looking for solutions in the question of the exportation of pharmaceuticals produced under } \\
\text { compulsory licensing for countries with little or no pharmaceutical manufacturing capacity } \\
\text { - Extending the transitional period regarding pharmaceutical patents for least-developed countries } \\
\text { until 01.01.2016 } \\
\text { - Setting the deadline for the end of negotiations regarding the multilateral registration system for } \\
\text { geographical indications of wines and spirits: } 5 \text { th Ministerial Conference in } 2003 \\
\text { - Besides the reviews required by the TRIPS Agreement, further reviews should also look at the } \\
\text { relationship between the TRIPS Agreement and the UN Convention on Biodiversity, the } \\
\text { protection of traditional knowledge and folklore and other developments } \\
\text { - Solution needed to be found for 'non-violation' complaints - in the meantime it is not possible to } \\
\text { initiate such complaints under TRIPS }\end{array}$ \\
\hline
\end{tabular}

30.08.2003

'Waiver' as a temporary solution for the issue regarding exportation of pharmaceutical products produced under compulsory licensing, making it easier for poorer countries to obtain cheaper generic versions of patented medicines

$10-14.10 .2003$

5th WTO Ministerial The conference was supposed to be a mid-term evaluation of the Doha Development Agenda, however it Conference, Cancún, ended without any consensus

Mexico

01.08.2004

The 'July package' agreed, highlighting the need for more intensive negotiations regarding implementation issues related to the extension of the protection of geographical indications to products other than wines and spirits, reporting deadline: May 2005

29.11.2005 The transition period is prolonged for least-developed countries. The new deadline: 01.07 .2013

- Final decision in the question of patented pharmaceuticals: the 'waiver' of 2003 transformed to a permanent amendment

- Agreement that the Doha Work Programme needs to be completed by the end of 2006

$13-18.12 .2005$

6th WTO Ministerial

Conference, Hong Kong

- The negotiations regarding the multilateral registration system for geographical indications of wines and spirits need to be finished

- Efforts need to be doubled to find solutions for implementation issues, such as the extension of the protection of geographical indications other than wines and spirits and the relationship between the TRIPS Agreement and the UN Convention on Biodiversity. These progresses need to be ready for review by 31.07 .2006

- Works regarding the 'non-violation' complaints need to be continued

\begin{tabular}{|c|c|}
\hline $\begin{array}{l}\text { 30.11 }-02.12 .2009 \\
\text { 7th WTO Minis } \\
\text { Conference, Geneva }\end{array}$ & $\begin{array}{l}\text { he Members agreed not to bring 'non-violation' complaints to the WTO dispute settlement process } \\
\text { ntil the final decision in the issue }\end{array}$ \\
\hline $\begin{array}{l}\text { 15- 17.12.2011 } \\
\text { 8th WTO Ministerial } \\
\text { Conference, Geneva }\end{array}$ & $\begin{array}{l}\text { - 'Non-violation' complaints remain excluded from the WTO dispute settlement process until a final } \\
\text { decision } \\
\text { - Decision about the review of the request of least-developed countries for the extension of their } \\
\text { transitional period. Final discussion of the issue: 9th WTO Ministerial Conference, } 2013\end{array}$ \\
\hline
\end{tabular}

(Source: own compilation of information fromwww.wto.org) 
"The WTO Agreement on Trade-Related Aspects of Intellectual Property Rights, the so called TRIPS Agreement, is based on a recognition that increasingly the value of goods and services entering into international trade resides in the know-how and creativity incorporated into them. The TRIPS Agreement provides for minimum international standards of protection for such know-how and creativity in the areas of copyright and related rights, trademarks, geographical indications, industrial designs, patents, layout-designs of integrated circuits and undisclosed information. It also contains provisions aimed at the effective enforcement of such intellectual property rights, and provides for multilateral dispute settlement. It gives all WTO Members transitional periods so that they can meet their obligations under it. Developed-country Members have had to comply with all of the provisions of the Agreement since 1 January 1996. For developing countries and certain transition economies, the general transitional period ended on 1 January 2000. For least-developed countries, the transitional period is 11 years (i.e. until 1 January 2006)" (WTO Annual Report, 2001).

The agreement on Trade-Related Aspects of Intellectual Property Rights (TRIPS) is often called a minimum standards' agreement due to the characteristic that it sets 'only' minimum requirements that the member countries have to meet but it provides space for them to implement laws and regulations which can provide better protection to intellectual property rights. The agreement and all the minimum standards follow three fundamental principles. Firstly, the principle of national treatment requires member countries to treat their own nationals and foreigners equally. Secondly, the most-favored-nation treatment requires equal treatment for the nationals of all WTO members and trading partners. While these first two principles represent the standard WTO principles, the third one is more specific directed to the TRIPS regime stipulating that its provisions should contribute to and encourage technical innovation and technology transfer.

Besides these principles the TRIPS agreement provides regulation by the use of common-ground rules which basically state that member countries have to follow the obligations of the most recent versions of the two most important agreements under the World Intellectual Property Organization (WIPO), namely the Paris Convention for the Protection of Industrial Property (in case of patents, industrial designs, etc.) and the Berne Convention for the Protection of Literary and Artistic Works (for copyrights). In cases where these treaties do not contain any relevant provisions or the ones contained are deemed to be inadequate, the TRIPS agreement provides further standards for all fields of IP protection (see generally on TRIPS, inter alia, Correa, 2001; Abbott, 2007: Abbott \& Correa, 2007; Gervais, 2008; Gervais, 2009; Gervais, 2011b).

- Copyrights and related rights: Members have to follow the regulations of Berne Convention (except for that of moral rights). Computer programs need to be treated as literary works, databases should be protected by copyright (not the data or material itself). Authors of computer programs and films and producers of sound recordings have to be given the right to authorize or prohibit the commercial rental of their works to the public. Performers and producers of sound recordings have to be protected from unauthorized recording and broadcast of live performances for a minimum of 50 years. Broadcasting organizations need to get such protection for 20 years.

- Trademarks: Marks able to distinguish goods and service marks must be protected by trademark and the owner must be given exclusive rights to use. Marks which became well-known must enjoy further protection. A registered trade mark must be guaranteed for a period of at least 7 years.

- Geographical indications: The highest level of protection must be given to wines and spirits. Members have to prevent the use of misleading indications. Exceptions can be used if a name already became a generic term in a country.

- Industrial designs:Industrial designs must be protected for 10 years.

- Patents:The provisions of the Paris Convention are valid. Moreover 20 years of patent protection must be available for all inventions in almost all fields of technology with three permissible exceptions: (i) if commercial use is prohibited because of the ordre public or morality, (ii) in case of diagnostic, therapeutic and surgical methods for the treatment of humans or animals, as well as (iii) in case of plants and animals other than micro-organisms and essentially biological processes for the production of plants or animals other than non-biological and microbiological processes. The applicant for the patent has to provide understandable (for experts) description of the invention and the production of it. Compulsory licensing and government use is allowed without the authorization of the right owner but the rights still need to be protected (for a discussion on contemporary public health issues within TRIPS see, inter alia, Abbott, 2011).

- Layout designs of integrated circuits: The basic regulation is the Washington Treaty on Intellectual Property in Respect of Integrated Circuits. Moreover protection must be given for at least 10 years. The rights need to be extended to articles incorporating infringing layout designs. Innocent infringers must 
be allowed to finish the use or sales of stock in hand which was ordered before knowing about the infringement. Government use is only allowed within strict regulations.

- Undisclosed information (trade secrets, know-how): Must be protected against unfair commercial activities. Materials about pharmaceuticals and agricultural chemicals waiting for marketing approval must also be protected.

- Control of anticompetitive practices: If a country finds out that practices for protecting IPRs are anti-competitive it can ask for consultation for the other member.

In contrast to many expectations, the inclusion of the TRIPS agreement into the WTO did not lead to a flood of complaints and cases (Pauwelyn, 2010: 5-9). From $1^{\text {st }}$ of January, 1995, and until the $20^{\text {th }}$ of September, 2011, 29 out 427 (= 6.8 per cent) disputes filed under the WTO framework related to TRIPS. From these 29 cases filed, 9 ( $=31$ per cent) were brought to a panel. Panel decisions were appealed in again 33 per cent of cases, which is considerably below the rate of appeals for panel decisions including all WTO areas (that is about 70 per cent). Furthermore, there is a downward trend in TRIPS disputes: 23 of 29 cases were filed in the period between 1996 and 2001(in the first six years of TRIPS). During the last almost 11 years, there have been only 6 TRIPS cases in total (see also Figure 1). Regarding the parties to the disputes, 9 out of 29 cases have been disputes brought by developed against developing countries, whereas 10 have been between the U.S. and the EU. The latter has been the most popular target (12 out of 29 complaints) so far - and the two most recent disputes saw developing countries bringing a case against developed countries.

From these figures it can be concluded that TRIPS has not been an instrument of developed countries to fight developing ones to this day (Pauwelyn, 2010: 8). While it is difficult to conclude anything about the adequacy of the number of cases, at least, it can be cautiously concluded that TRIPS complaints and cases are not that much popular among WTO members.

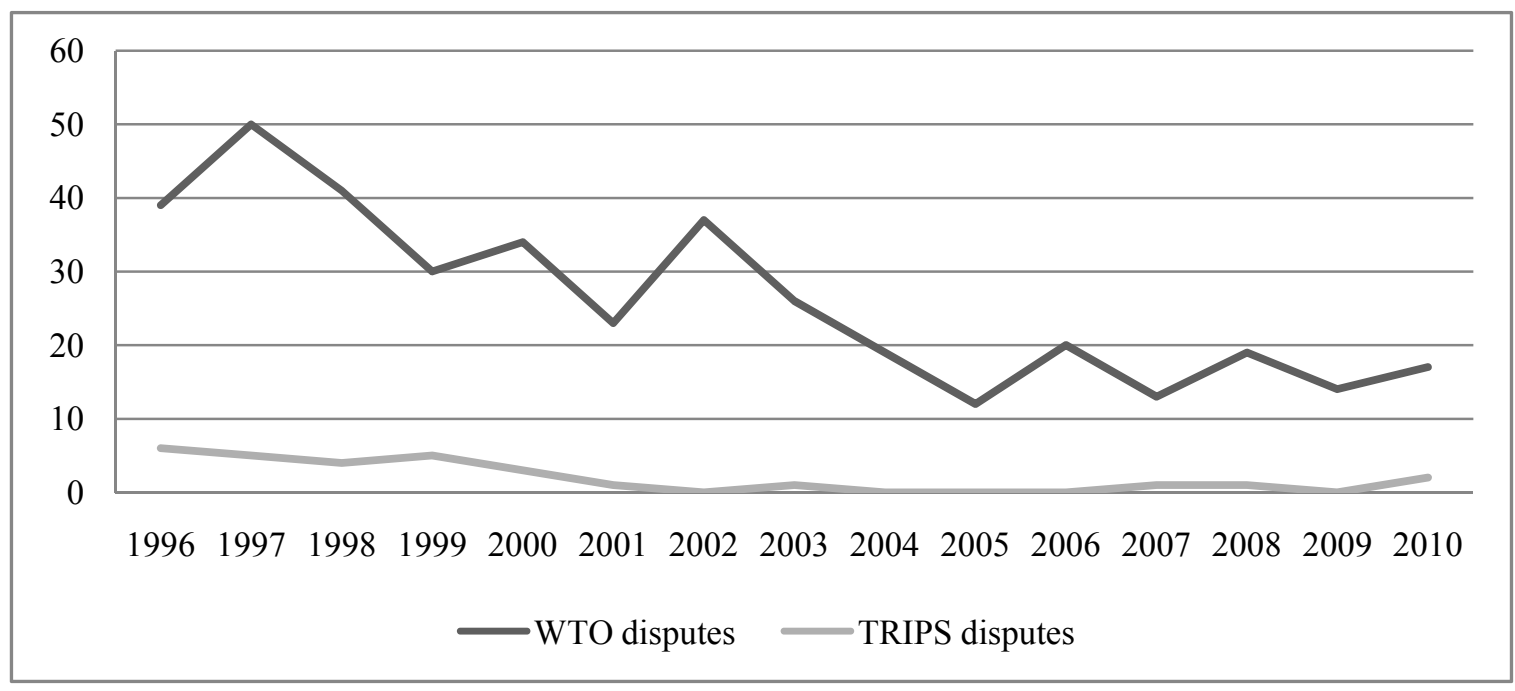

Figure 1. WTO-TRIPS Disputes Filed (1996-2010)

Sources: Pauwelyn (2010: 7) with additional data from http://www.wto.org/english/tratop_e/dispu_e/dispu_agreements_index_e.htm?id=A26\#selected_agreement and http://www.wto.org/english/tratop_e/dispu_e/dispu_status_e.htm.

\subsection{Current Developments}

At the moment and in the last couple of years there have been predominantly four main topics under discussion in the area of the TRIPS Agreement (Note 5). These are negotiations regarding (i) geographic indications, (ii) incentives for technology transfer, (iii) 'non-violation' complaints as well as(iv) the protection of biodiversity and traditional knowledge.

\subsubsection{Ongoing Negotiations Regarding Geographical Indications}

Geographic indications (GIs) are usually names of geographic places which can help to identify certain characteristics of different products. In general, GIs include information for consumers not only about the place 
of origin but also contain signaling of quality and reputation standards of a given product (Note 6).In the TRIPS Agreement, Art. 22 man dates all member countries to provide a standard level of protection for all products. This minimum standard must avoid misleading information of products about their GIs towards the public as well as the use of GIs for unfair competition (Note 7). Besides Art. 22, in case of wines and spirits, Art. 23 provides a higher level of protection, meaning that these products have to be protected even if the misuse of GIs would not cause any misleading of consumers or the public. In Art. 24, the agreement provides some exceptions regarding commonly used terms or long-standing practices and traditional names.

In the area of GIs, there are two main issues debated: (i) implementing a multilateral register for wines and spirits and (ii) extending the higher level of protection for wines and spirits to other products as well.

Regarding a multilateral register for wines and spirits, the key questions of the discussion are: what legal effect would a registration of a product have within member countries? To what extent this effect should apply to countries which are not part of the system? What about costs and benefits? The discussion traces back to an EU proposal. The general idea is that if a GI is registered, it establishes a "rebuttable presumption" that the term is to be protected in all WTO countries, unless a country makes a reservation within a specified period to be able to refuse protection. Many member states merely want to accept a voluntary system for the registration which would only be effective for countries opting to participate (Ahmad, 2005). Recently, a compromise proposal by Hong Kong and China surfaced that includes registration only on a voluntary basis, but the terms registered would enjoy a limited "presumption".

Regarding an extension of the higher level of protection beyond wines and spirits, the key questions of the debate are: does the Doha Declaration provide mandate for such negotiations? Is it useful at all to extend the higher level of protection? If yes, to what extent? As the main interests in favor of such an extension, countries like Bulgaria, the EU, Guinea, India, Jamaica, Kenya, Madagascar, Mauritius, Morocco, Pakistan, Romania, Sri Lanka, Switzerland, Thailand, Tunisia and Turkey argue that the extension would help them market their products more effectively and also to be able to differentiate them from competitors' goods. In contrast, the opposing countries (Argentina, Australia, Canada, Chile, Colombia, the Dominican Republic, Ecuador, El Salvador, Guatemala, Honduras, New Zealand, Panama, Paraguay, the Philippines, Chinese Taipei and the United States) emphasize that the existing level of protection is sufficient. The extension would be a burden and would cause problems with the existing marketing practices. Basically they argue that the extension of GIs would be very harmful for producers who do not belong to the area which is protected by the GI. In their case, the resulting costs of developing and establishing new marketing strategies would include, inter alia, administration costs due to the name change and all the expenses they would need to spend on promotion (looking for new names, building trust of consumers, .etc.). Moreover, these established products would appear to be 'new' for consumers without having the advantage of possessing innovative characteristics, thus eroding the investment in building up these brands and products and the accompanying reputation (WTO, 2005).

At the moment in both issues the Members try to get their interests closer to each other, however there is no agreement in sight yet (Ilbert \& Petit, 2009).

\subsubsection{Incentives for Technology Transfer}

Technology transfer is regarded by least-developed countries as part of the bargain in which they have agreed to protect intellectual property rights. Thus these countries regularly demand a more effective operation of technology transfer initiatives and incentive schemes. In general, many different articles deal with the question of technology transfer. However, Art. 66 (2) obliges developed countries to provide incentives for technology transfer to enterprises and organizations within their territories. In order to make this system operate more effectively, the Doha Declaration states that developed countries must provide a detailed report by the end of each year which answers several questions regarding the operation of their incentive systems.

As another part of these efforts, the WTO Secretariat has already organized workshops to discuss the issues and questions of technology transfer. Some of the developed-country members were invited to explain their incentive systems in detail. Moreover experts from both sides were able to discuss the operation of the system and how it could be improved. The basic idea behind these workshops was to achieve a broader understanding of the incentives and to provide a place for dialogue between the countries. At the same time other decisions under the TRIPS agreement have raised the question of technology transfer and, additionally, climate change negotiators have also started to discuss this topic.

The major sources of technology transfer (TT) are usually said to be trade, licensing, foreign direct investment, joint ventures, the movement of people, etc. Basically two main types of TT are distinguished (Foray, 2009; WTO, 2011): 
- packaged form: the technology is transferred through investments, import of goods or building projects by foreign firms. In these cases, the transferred technology is a joint product or a by-product of another economic activity.

- unpackaged form: technology is not transferred through a direct investment or trade but rather through licensing or collaboration contracts, consultancy or joint ventures. In these cases, TT is the primary economic activity and not a 'side-effect'.

Examples for technology transfer under TRIPS include the following two programs (Foray, 2009; WTO, 2011):

- Collaboration between Switzerland's State Secretariat for Economic Affairs, the UN's Industrial Development Organization and many developing countries.

- Swiss-supported Cleaner Production Centers (CPC) offer different services and solutions for clean technologies. CPCs are autonomous bodies, with their own boards, representing local industries and services; however, they are supported by a Swiss Reference Center - a distinguished institution in the relevant area.

- The provided services are, for instance, information on the newest technologies, consultancies and special services, such as eco-audits, project evaluation, introduction to ISO standards, support in the investment projects, training, etc.

- The CPCs also help local entrepreneurs to find solutions for financing technologies.

- US National Institutes for Health (NIH) support a "Global Research Initiative Program for New Foreign Investigators (GRIP)".

- The program supports the re-entry of NIH-trained foreign researchers into their home countries by providing partial salaries to these "returning home researchers" and by supporting their research projects.

- The aim of this program is to enhance the scientific research infrastructure in developing countries, to stimulate research and to widen the efforts for finding solutions to global health issues.

\subsection{3 'Non-violation' Complaints}

In the WTO and thus also under the TRIPS agreement if a member notices that another country has violated the Agreement or broke a commitment, it can turn to the Dispute Settlement Body (DSB). However the WTO also provides space for other kinds of complaints, namely the 'non-violation' ones when the 'letters of the agreement' do not get violated, however the member can show that it has been deprived of an expected benefit because of another country's decision or action. These 'non-violation' complaints are possible in the case of goods and services in order to keep the balance of benefits. However in case of the TRIPS agreement the picture looks more complicated. Originally, Art. 64 (2) of the TRIPS Agreement contained a five-year long moratorium on this question (meaning until 2000). Since then this moratorium has been extended from one ministerial conference to the following one and there has been no agreement about these kinds of complaints.

The main questions of the controversial negotiations are: should 'non-violation' complaints be allowed in connection to intellectual property rights? If so, to what extent and how could these issues be included in the WTO dispute settlement processes? Up to date there are some (e.g. the U.S. and Switzerland) who are positive towards this question and they would be open to negotiate the details of allowing 'non-violation' complaints under the TRIPS agreement. However until date there has been no consensus on the issue so the moratorium has been extended again until the ministerial conference of 2013.

\subsubsection{Protection of Biodiversity and Traditional Knowledge}

The negotiations about the protection of biodiversity and traditional knowledge are based on two main topics. Firstly, Art. 27.3(b) of the TRIPS Agreement deals with the patentability of animal and plant inventions and the protection of new plant varieties. Moreover, since the Doha Declaration, the debates also include issues regarding the relationship between the TRIPS agreement and the UN Convention on Biological Diversity (CBD) as well as the protection of traditional knowledge and folklore.

The debate centers on questions like whether and how TRIPS should do more to promote the CDB objective of equally sharing the benefits coming from the use of genetic resources in research and industry. The views of the different groups of members cover a wide range; however the main proposals focus mostly on amending the TRIPS agreement to require patent applicants to disclose the source providing genetic resources and the needed traditional knowledge. Most of the members inject their proposals about a special form of disclosure, either as a TRIPS obligation or through the WIPO (World Intellectual Property Organization) or outside the patent law. There are other members, though, who would rather rely on national legislation, including contracts, than on a 
disclosure obligation.

Views and ideas on the topic of the protection of biodiversity and traditional knowledge differ considerably and up to date there is no consensus in sight. However, all members agree that steps need to be taken to avoid erroneous patents and to equally share the benefits.

\subsection{TRIPS and the Challenge of Commercial Copyrights}

Interestingly, the internally chosen agenda of development and reform projects within TRIPs (as discussed in this section 3) does not refer to the issue of cross-border enforcement of commercial copyrights. This represents an important fact in the light of two recent developments. Firstly, cross-border commercial copyrights have been an important enforcement problem within TRIPS so far (section 4) and, secondly, innovation dynamics in media markets create relevant new challenges for the international governance of this issue (section 5).

\section{Selected Cases}

Table 3 lists the 9 cases that have been decided before a panel so far under the TRIPS agreement. Pauwelyn (2010: 10-12) convincingly argues that most of these cases could also have been dealt with under the other WTO agreements, so that merely a small number of three cases remains that represents the core of TRIPS decisions (grey-shaded in Table 3). Among these cases, two are deemed specifically interesting because they touch on the core of intellectual property rights protection in the WTO framework. According to Gervais (2011a), the Google Book Digitalization Settlement may provide scope for another spectacular copyright case under TRIPS.

Table 3. TRIPS Panel Cases

\begin{tabular}{lc}
\hline \multicolumn{1}{c}{$\begin{array}{c}\text { PANEL REPORTS } \\
\text { making TRIPS findings }\end{array}$} & \multicolumn{1}{c}{$\begin{array}{c}\text { APPELLATE BODY REPORTS } \\
\text { making TRIPS findings }\end{array}$} \\
\hline 1. India - Patent (US) & India - Patent (US) Jan. 1998 \\
2. Indonesia - Autos (EC, Japan, US) & \\
Jul. 1998 & \\
3. India - Patent (EC) Sept. 1998 & \\
4. Canada - Pharmaceutical Patents (EC) & \\
Apr. 2000 & \\
5. US - Copyrights (EC) Jul. 2000 & Canada - Patent Term (US) Oct. 2000 \\
6. Canada - Patent Term (US) & US - Havana Club (EC) Feb. 2002 \\
7. US - Havana Club (EC) & \\
8. EC - Trademarks \& Geographical & \\
Indications (US/Australia) Apr. 2005 & \\
9. China - IP Rights Mar. 2009 & \\
\hline
\end{tabular}

Source: Pauwelyn (2010: 10).

\subsection{China - IPR}

The first case is the China - Intellectual Property Rights case (WTO Dispute (DS362); China, 2007; Fukunaga, 2008; Pauwelyn, 2010) (Note 8).On the $10^{\text {th }}$ of April, 2007, the United States submitted a complaint to the WTO Dispute Settlement Body which dealt with different aspects of the question of enforcing intellectual property rights in China and asked for consultations. After the submission of the complaint several WTO members joined the consultations and the WTO established a panel which was investigating the issues under debate. After more than one and a half year of consultations the final report was circulated among the members. Regarding some of the complaints the panel found that the Chinese practices did not break the words of the law, however, in other cases rules and practices in China were ruled to be inconsistent with the obligations of the TRIPS agreement.

The complaint submitted by the US was basically built around three main issues of intellectual property rights.

- Firstly, the US asked for consultation on the question of threshold levels which had to be reached in China in case of willful trademark counterfeiting (Note 9) or copyright piracy issues in order to become 
subjects to criminal procedures and penalties. Moreover, the US also complained about the respective enforcement activities (or lack of it). In these regards the US accused China's institutions and practices to be inconsistent with Articles 41.1 and 61 of the TRIPS agreement. The arguments focused on the procedural rules in China which stated that willful trademark counterfeiting and piracy were only supposed to be subject to criminal investigations and penalties if the case was 'serious' or 'especially serious' or the scope was 'relatively large' or 'huge'. These terms were not determined by law and with the help of previous judicial interpretations, the US demonstrated that these amounts were usually calculated from the relative prices of the infringing materials compared to the legitimate prices which meant that the lower the price was, the bigger amount the infringer could sell without risking a criminal procedure. Moreover, the US also showed that Chinese regulations only regarded unauthorized reproduction and unauthorized distribution as illegal activities if these were done together, meaning that one of these was accompanied by the other. Following the investigation, the panel rejected the claim of the United States ruling that the complainant did not prove that the threshold levels in China allow for an infringement on a commercial level. Thus, the respective rules and practices in China were ruled to be not inconsistent with the provisions of TRIPS.

- The second point in the complaint focused on the disposal of works confiscated by the Chinese customs authorities due to the infringement of intellectual properties. In this regard the US showed that the Chinese authorities were required to put these goods back to the channels of commerce (for example by auctions) after removing the infringing features. The US argued that such practices were inconsistent with Articles 46 and 59 of the TRIPS agreement. After the consultations and examination, the panel decided to partially agree with the complaint, concluding that the simple removal of the infringing features (e.g. a brand name or symbol) of the confiscated goods before putting them back into commercial channels was not consistent with Article 59 of TRIPS Agreement. Otherwise, however, the panel concluded that the US had not demonstrated the inconsistency of the Chinese practices with the articles of the TRIPS agreement, i.e. it is not per se inconsistent with TRIPS to re-introduce counterfeited good into the channels of commerce once the infringing character of the confiscated goods has been sufficiently removed or altered.

- The third main area of the complaint was concentrating on the censorship processes. China denied copyright protection and other IPR to works and creations which had not yet fully concluded the authorization process. In other words, works that were (still) under inspection with the so-called content review system or failed to pass it did not enjoy any copyright (etc.). IP owners whose creations had not been authorized in China were not able to enforce any rights on these works and creations. The US concluded that all these issues were inconsistent with Articles 3.1, 9.1, 14 and 41.1 of the TRIPS agreement. Following the investigation, the decision of the panel was straight and obvious as it upheld the claim and concluded that the existence of the content review system did not provide any justification for denying copyrights and other related rights for any works or creations, including such that failed the authorization procedure. So in this regard the panel concluded that China's laws and practices were inconsistent with several provisions of the TRIPS agreement.

In its final report, the panel recommended China to bring its 'problematic' regulations into conformity with its obligations under the TRIPS agreement. After the final report was published, China informed the Dispute Settlement Body that it intended to make the changes required and that it agreed with the US that the deadline to do so would be the $20^{\text {th }}$ of March, 2010. One day before the deadline China reported that it had completed all procedures to implement the recommendations.

\subsection{The US - Copyrights}

The second case is the U.S. - Copyrights case (Pauwelyn, 2010: 12, 15, 23-26, 38-39; United States, 2012 - also for the following) (Note 10). On the $26^{\text {th }}$ of January, 1999, the European Communities requested consultation with the United States in the question of copyrights. They argued that certain exemptions under Section 110(5) of the U.S. Copyright Act were inconsistent with Article 9(1) of the TRIPS agreement which incorporates the obligations that members were required to comply with under the Berne Convention. These exemptions allowed under certain conditions the amplification of music broadcasts in public areas without authorization or the payment of a fee. The European Communities argued that these exemptions were inconsistent with Article 13 of the TRIPS agreement.

Following one and a half year of investigation the panel partially upheld the claim of the European Communities and recommended the U.S. to complete the needed changes in its regulatory system to be consistent with the obligations under the TRIPS agreement. 
More detailed, the complaint submitted by the European Communities focused on two exemptions of Section 110(5) of the U.S. Copyright Act:

- Sub-paragraph (A) of the Act dealt with the so-called homestyle exemption. This part of the regulation provided the possibility for small restaurants and retail outlets to amplify music broadcasts without the need for any authorization from the right holders or the payment of a fee. However, this exemption was only valid if these public places used so-called homestyle equipment, meaning such apparatus which were usually used in private homes. In case of this point the panel conducted the investigation and then found that the homestyle exemption was not inconsistent with Art. 13 of the TRIPS Agreement. The panel concluded that the economic impact of the homestyle exemption was negligible and, thus, in accordance with TRIPS Art. 13, it could be deemed to be a limited and special case that does not represent a normal exploitation of the work.

- The other area under investigation was the sub-paragraph (B) of the Act, containing the so-called business exemption which provided the same possibilities for a much larger scale of food service and drinking establishments and retail establishments. In more details this exemption made it possible for such places to amplify music broadcasts without permission from the owners of the copyrights and related rights and without the payment of a fee if these units did not exceed a certain square footage limit. Moreover establishments larger than this limit could also enjoy the exemption if they met given limitations about the equipment used for music broadcasting. In the case of the business exemption the panel finally found that it was not consistent with Art. 13 of the TRIPS agreement. Their reasoning focused on the fact that most of the food service and drinking establishments belonged to the area of this regulation and, thus, it does not qualify to be a limited special case. Instead, the business exemption exempts a practice of normal exploitation of the music rights from IP protection and therefore violates the TRIPS agreement.

Following the investigation, the final report of the panel was circulated among the members on 15 June 2000. In order to implement the recommendations, the United States asked for 15 months as a reasonable period to complete all procedures. However, as the European Communities did not agree with the length of this period, the final timescale was determined by binding arbitration which concluded that the reasonable period for implementation was 12 months, with the deadline of 27 July 2001.On its meeting three days before the end of the reasonable period provided for the U.S., the Dispute Settlement Body and also the European Communities agreed to the proposal to extend the period until the end of 2001 or that of the current session of the US Congress - whichever was earlier. However, on the $7^{\text {th }}$ of January, 2002, the U.S. had still not completed all the implementation requirements so the European Communities requested authorization to suspend concessions pursuant to Article 22.2 of the Dispute Settlement Body. In this regard the European Communities stated that it would fix a certain fee from US nationals in connection with border measures regarding copyright works to make sure that the benefits of the U.S. from the existence of the business exemption would not exceed the nullified or impaired benefits of the European Communities (this amount was previously determined by arbitration). A few days later the United States stood against the suspensions suggested by the European Communities and also stated that certain principles and procedures were not followed. On a meeting on $18^{\text {th }}$ of January, 2002, the parties finally agreed on continuing the process with constructive negotiations. Eventually, on the $23^{\text {rd }}$ of June 2003, the United States and the European Communities informed the Dispute Settlement Body that they had made a mutually satisfactory temporary agreement, covering the period until the $20^{\text {th }}$ of December, 2004. This agreement contained the maintenance of the business exemption by the U.S. and the annual payment of an impairment compensation for the ongoing violation to the EU. For this three-year-period, the U.S. paid s total of US\$ 3.3 million to the EU, calculating against the background of the estimated counterfactual royalties that would have been collected if the business exemption had not existed (differences-in-differences approach). However, since that date, the U.S. has neither paid any impairment compensation nor withdrawn or reformed the business exemption. Meeting-by-meeting, the EU brings the issue up on the agenda of the Dispute Settlement Body and meeting-by-meeting the U.S. submits identically phrased (!) reports, stating that it is working on an implementation of revised rules. The last $\left(85^{\text {th }}\right)$ such report until date was submitted on the $10^{\text {th }}$ of January, 2012.

\section{International Governance of Intellectual Property Rights: The Limits of TRIPS and New Developments}

The US - Copyrights case discussed in the preceding section touches upon a viral topic of international IPR protection which is the cross-border enforcement of copyrights, here music copyrights. At the same time, it represents a traditional case in the sense that it is not about internet or piracy, two phenomena that tend to dominate the debate about cross-border copyright enforcement. However, it should not be overlooked that even traditional payment systems for copyright owners in entertainment industries remain problematic. The question 
is: how can IPR holders collect their royalties (= enforce their copyrights) abroad, for instance, like in this case, if their music is played in restaurants and bars abroad or used in other business contexts. In this regard, the WTO procedure in U.S. - Copyrights demonstrates two - somewhat contradictory - conclusions: on the one hand, TRIPS is applicable and the panel clearly ruled that U.S. practices à la business exemption, denying foreign copyright holders their royalties, violate the agreement. On the other hand, nothing substantial appears to have happened since the ruling. Instead, the U.S. issues year-by-year exactly the same 'solution delayed' report to the WTO without actually solving the underlying problem. This does not suggest an effective enforcement of the ruling.

However, one should be cautious to underestimate the TRIPS effect on cross-border copyright enforcement. The so-called allofmp3.com case offers an interesting example. The story is about a Russian music downloading platform that was long deemed to be legal under Russian laws despite selling downloads of foreign copyright owners without offering any (adequate) compensation to the IPR holders (Benko, 2007). When Russia approached WTO membership, its IPR policy was viewed to be a main obstacle to an agreement (Katz \& Ocheltree, 2006). And when such an agreement between the WTO and Russia eventually was on the horizon, Russia 'suddenly' changed its policy towards allofmp3.com and its related enterprises and effectively terminated its business. Although the U-turn in policy and law enforcement was not officially put in the context of the upcoming WTO membership, the shadows of TRIPS might well have been a trigger for changing a national copyright policy that most likely would have led to a lost case in front of the TRIPS panel (Note 11). In other words, the pure existence of TRIPS can have a disciplinary effect on members and accession candidates.

The TRIPS agreement represents a multilateral approach to IPR protection and, thus, already a comparatively centralized approach to international IPR governance. However, even though the WTO-TRIPS agreements cover 157 member states and, therefore, the big majority of the world and of world trade, it is still not a truly global regime. And with a view to internet as the medium which appears to be the cornerstone of intellectual property right violations and enforcement, having some safe-harbors for server locations outside TRIPS may be sufficient to hamper the regulatory effect of TRIPS. It has to be kept in mind that the nature of the combination of the internet as a truly worldwide transmission channel and digitalized products (with real copy costs tending towards zero without any loss in quality) implies that even small territories outside the scope of WTO/TRIPS may create huge loopholes for cross-border copyright enforcement. Talking about copyrights for music, movies, writings and others, already few servers outside the WTO-TRIPS jurisdiction may be able to flood the common markets of the WTO members with copyright-violating products, thus, de facto eroding any protective effect of TRIPS for digitalized products that are traded via the internet. And this would even be true if cross-border copyright enforcement within the WTO-TRIPS jurisdiction worked perfectly (which represents a heroic assumption as of today). It is the nature of the TRIPS agreement that it cannot develop any extraterritorial effects outside the WTO jurisdiction (possibly except of countries that aspire to a membership).

From an economic perspective, a de facto erosion of enforceable commercial copyrights represents a welfare problem. As has been argued in section 2, an erosion of effective IPR harms the incentive to produce new creations in the future and, thus, handicaps and impedes innovation dynamics. Furthermore, the typically discussed trade-off with abuse of market and monopoly power by the IPR owners tends to be considerably less relevant with commercial copyrights, since these types of IPR tend to exist in competitive settings and do not come along with considerable market or even monopoly power (see section 2) (Note 12). Consequently, loopholes in international governance that enable digital piracy and counterfeited products to flood these markets are very likely to be strongly welfare-reducing in their total effects in real-world scenarios. Economic analysis shows that imperfect IPR protection can only have positive welfare effects, if two assumptions hold: (i) IPR owners enjoy a monopoly-like market position (according to a state-of-the-art economic market delineation) and (ii) consumers prefer the original over the (illegal) copy. Only if these two assumptions hold, violations of IPR may (but not necessarily will) have other than negative welfare effects (Note 13). This is hardly the case with commercial copyrights and would require to be thoroughly demonstrated for exceptional cases.

Against the background of the preceding paragraphs, it is not surprising that initiatives to create an extraterritorial power to enforce copyrights in the internet across borders are currently (and controversially) discussed. This goes hand in hand with a re-nationalization - or re-decentralization - of copyright enforcement policies since the TRIPS system is not viewed to offer any avenue to close down on the loopholes of copyright enforcement in the digitalized internet economy. At the same time, this implies that economically justified (or at least justifiable) cross-border copyright enforcement goals can become mixed with other goals regarding internet governance, such as fighting other internet crimes (like child pornography), reducing the anonymity of internet users, limiting privacy for political or commercial reasons, etc. When talking about initiatives like SOPA and 
PIPA (U.S.), the issue of cross-border copyright protection and enforcement gets easily thrown into the mix of these other implicit or explicit goals and while protest and resistance by internet lobby groups is widespread and fierce, it is often difficult to disentangle the different elements and to identify whether all goals and elements are actually targeted. In order to round the discussion on this paper, we will focus exclusively on TRIPS-related elements of the new initiatives and not dive into the other issues and goals.

The PROTECT IP Act (Preventing Real Online Threats to Economic Creativity and Theft of Intellectual Property Act, PIPA) is a proposed law in the United States, introduced in May 2011. The basic idea of the Act is to give stronger power into the hands of the US Government and intellectual property right holders. Besides PIPA, a similar House version of the bill also exists, namely the Stop Online Piracy Act (SOPA) which was introduced in October 2011 (Note 14).SOPA and PIPA include TRIPS-relevant provisions insofar as cross-border copyright enforcement is concerned. According to these acts, internet sites which are obviously created in order to infringe IPR, in particular by distributing goods illegally or facilitating it or contributing to it, would fall under US jurisdiction irrespective of their place of origin. Thus, the new regulations would include a direct extraterritorial reach as soon as domestic markets are affected (which in case of the internet is virtually always the case). This approach resembles the effects doctrine as known from antitrust laws and competition policy enforcement (inter alia, Griffin, 1999; Fox, 2003; Budzinski, 2008).

However, more far-reaching effects would have to be expected from an indirect extraterritorial enforcement mechanism incorporated into the acts. All those parties (other websites, service providers, advertising agencies, search engines, etc.) who are either in financial relationship with the infringing site or link to it, would have to stop all activities towards the site and remove links referring to it (in case of internet providers, they would even have to block access to the infringing page) (Note 15). In other words, a joint liability of (i) providers, (ii) intermediates (search engines, archives, data banks, online encyclopedias, etc.), and (iii) commercial partners (e.g. advertisers) would be introduced. Furthermore, instead of 'just' removing connections to infringing sites on request, these three groups would be required to actively search for infringing 'partners' and proactively employ the required sanctions on them. Once again, all these regulations would also be valid for sites which are registered outside the US, creating an indirect extraterritorial enforcement channel.

These unilateral extraterritorial enforcement mechanisms may stand in conflict at least with the idea of TRIPS. On the one hand, this refers to the intended role of providers and intermediates as auxiliary policemen of copyright enforcement. On the other hand, an extraterritorial reach of US copyright protection policy would limit or even erode the national copyright rule-making competence above the TRIPS minimum standards of WTO member states (Note 16). Assuming that the intended enforcement mechanisms would be effective, US copyright rules would prevail worldwide (at least, this appears to be part of the intention), thus, offering no scope for differing national regulations 'on top' of the minimum standards. More precisely, only such national regulations that include the U.S. level and the U.S. way of IP protection (and may even go beyond it) may prevail to exert considerable effects. All types of national regulations that locate "between" the TRIPS minimum standards and the U.S. style, either by providing IP protection above TRIPS but below PIPA or by employing other ways to create copyright protection (for instance, without involving search engines as deputy sheriffs), would be likely to face difficulties in exerting actual effects since they would be likely to get dominated by the U.S. extraterritorial enforcement (claiming jurisdiction according to U.S. standards over most relevant cases due to the cross-border nature of the internet). Effective extraterritorial enforcement always implies that the strictest regulation prevails for cross-border cases - and with the internet, virtually all relevant cases display cross-border effects (or have the potential to do so). Different stages of development but also cultural issues, however, may imply that a diversity of national copyright protection and enforcement on top of the minimum standards would be efficient and beneficial. It is rather doubtful if a one-size-fits-all approach through unilateral extraterritorial enforcement corresponds to individual levels of satisfying commercial copyright protection - in particular when it comes to a strictest-regulation-rules standard (extraterritorial enforcement approach) instead of defining common, worldwide consensual, minimum standards (TRIPS approach) (Note 17).

From an economic perspective, additional disadvantages of recidivism to unilateral strategies to enforce commercial copyrights include negative externalities from unilateral initiatives (seeking to maximize national welfare and not international welfare, thus favoring beggar-my-neighbor strategies), jurisdictional conflicts and disincentives for technology transfer and cross-border IP-related investments.

\section{Conclusions}

Our review of the hitherto intellectual property rights policy within the WTO framework shows that in particular the problem of the cross-border enforcement of commercial copyrights represents as well as remains a challenge 
and plays an important role in landmark TRIPS cases. Even in more traditional media markets the TRIPS provisions and procedures cannot efficiently solve cross-border commercial copyright under-enforcement as the US-Copyrights case demonstrates. At the same time, its reflection in the current discussion topics of the politically-dominated - TRIPS rounds appears to be surprisingly underrepresented and outshone by political topics with strong political lobby influences like geographic indications, technology transfer or biodiversity (see section 3.2). This represents a problematic development, especially in the light of the current re-emergence of unilateral initiatives to strengthen the cross-border enforcement of commercial copyrights by several nations, including plans to establish extraterritorial enforcement of national copyrights rules. From an economic point of view, turning away from the multilateral approach within the WTO framework (TRIPS) - but also from other multilateral forums like WIPO - represents a problematic tendency that can be expected to be less favorable from a world welfare perspective than reinforcing the commitment to multilateral solutions, reformed and adjusted to the new digital media challenges, even though such a process is guaranteed to be anything else than easy. Potential conflicts of those unilateral initiatives with TRIPS (and WIPO) provisions are likely to cause further problems and complications in the cross-border enforcement of commercial copyrights.

\section{Acknowledgements}

The authors thank Oliver Jennissen, Nadine Neute, the anonymous referees, and the participants of the $45^{\text {th }}$ Radein Research Seminar (February 2012) for valuable comments on earlier drafts of this paper as well as Sharyn Zwerenz for valuable editorial assistance.

\section{References}

Abbott, F. M., \& Correa, C. M. (2007). World Trade Organization Accession Agreements: Intellectual Property Issues. Quaker United Nations Office Global Economic Issues Publication. Retrieved from http://ssrn.com/abstract=1915338

Abbott, F. M. (2007). Intellectual Property Rights in World Trade. In A. T. Guzman, \& A. T. Sykes (Eds.), Research Handbook in International Economic Law (pp. 444-484). Cheltenham: Edward Elgar.

Abbott, F. M. (2011). Intellectual Property and Public Health: Meeting the Challenge of Sustainability. Global Health Programme Working Paper, 07-11. Retrieved from http://ssrn.com/abstract=1965458

Ahmad, M. (2005). Special Session of the Council FOR TRIPS, Report by the Chairman, Ambassador Manzoor Ahmad, to the Trade Negotiations Committee (TN/IP/13) - Official Document of the World Trade Organization.

Belleflamme, P., \& Peitz, M. (2012). Digital Piracy: Theory. In M. Peitz, \& J. Waldfogel (Eds.), The Oxford Handbook of the Digital Economy (pp. 489-530). Oxford: Oxford University Press.

Benko, B. A. (2007). Russia and Allofmp3.com: Why the WTO and WIPO Must Create a new System for Resolving Copyright Disputes in the Digital Age. Akron Intellectual Property Journal, 1(2), 299-335.

Budzinski, O. (2008). The Governance of Global Competition. Cheltenham: Edward Elgar.

China. (2007). Measures Affecting the Protection and Enforcement of Intellectual Property Rights - Request for Consultations by the United States (IP/D/26) - Official Document of the World Trade Organization, 16.04.2007.

Correa, C. M. (2001). The TRIPS Agreement: How Much Room for Maneuver? Journal of Human Development, 2(1), 79-107. http://dx.doi.org/10.1080/14649880120050192

Foray, D. (2009). Technology Transfer in the TRIPS Ages: The Need for New Types of Partnerships between the Least Developed and Most Advanced Economies. International Centre for Trade and Sustainable $\begin{array}{lllll}\text { Development (ICTDS) Issue Paper, } & \text { 23. } & \text { Retrieved from }\end{array}$ http://www.iprsonline.org/New\%202009/foray_may2009.pdf

Fox, E. M. (2003). Can We Solve the Antitrust Problems by Extraterritoriality and Cooperation? Sufficiency and Legitimacy. The Antitrust Bulletin, 48(2), 355-376.

Fukunaga, Y. (2008). Enforcing TRIPS: Challenges of Adjudicating Minimum Standards Agreements. Berkeley Technology Law Journal, 23(2), 867-931.

Gervais, D. J. (2008). The TRIPS Agreement: Drafting History and Analysis. London: Sweet \& Maxwell.

Gervais, D. J. (2009). TRIPS 3.0 - Policy Calibration and Innovation Displacement. In C. Thomas (Ed.), Developing Countries in the WTO Legal System (pp. 363-393). Oxford: Oxford University Press. http://dx.doi.org/10.1093/acprof:oso/9780195383614.003.0014 
Gervais, D. J. (2011a). The Google Book Settlement and the TRIPS Agreement. Stanford Technology Law Review, 1, 1-10.

Gervais, D. J. (2011b). Agreement on Trade-related Aspects of Intellectual Property Rights. Max Planck Encyclopedia of International Law. Oxford: Oxford University Press.

Gordon, W. J., \& Watt, R. (2003). The Economics of Copyright: Developments in Research and Analysis, Cheltenham: Edward Elgar.

Griffin, J. P. (1999). Extraterritoriality in U.S. and EU Antitrust Enforcement. Antitrust Law Journal, 67(1), 159-199.

Grossman, G. M., \& Shapiro, C. (1988a). Counterfeit-Product Trade. American Economic Review, 78(1), 59-75.

Grossman, G. M., \& Shapiro, C. (1988b). Foreign Counterfeiting of Status Goods. The Quarterly Journal of Economics, 103(1), 79-100. http://dx.doi.org/10.2307/1882643

Henry, C., \& Stiglitz J. (2010). Intellectual Property, Dissemination of Innovation and Sustainable Development. Global Policy, 1(3), 237-251. http://dx.doi.org/10.1111/j.1758-5899.2010.00048.x

Hurt, R. M., \& Schuchman, R. M. (1966). The Economic Rationale of Copyright. American Economic Review, $56(1 / 2), 421-432$.

Ilbert, H., \& Petit, M. (2009). Are Geographical Indications a Valid Property Right? Development Policy Review, 27(5), 503-528. http://dx.doi.org/10.1111/j.1467-7679.2009.00457.x

Katz, S., \& Ocheltree, M. (2006). Intellectual Property Rights as a Key Obstacle to Russia's WTO Accession. Carnegie Papers, 73. Washington, D.C.

Kerber, W., \& Schwalbe, U. (2008). Economic Principles of Competition Law. In F. J. Säcker et al. (Eds.), Competition Law: European Community Practice and Procedure (pp. 202-393). London: Sweet \& Maxwell.

Kireeva, I., \& O'Connor, B. (2010). Geographical Indications and the TRIPS Agreement: What Protection Is Provided to Geographical Indications in WTO Members? The Journal of World Intellectual Property, 13(2), 275-303. http://dx.doi.org/10.1111/j.1747-1796.2009.00374.x

Kirzner, I. M. (1992). The Meaning of Market Process. London and New York: Routledge. http://dx.doi.org/10.4324/9780203004456

Koboldt, C. (1995). Intellectual Property and Optimal Copyright Protection. CSLE Discussion Paper, 95-01.

Landes, W. M., \& Posner, R. A. (1989). An Economic Analysis of Copyright Law. The Journal of Legal Studies, 18(2), 325-363. http://dx.doi.org/10.1086/468150

Mulik, K., \& Crespi, J. M. (2009). Geographical Indications and the Trade Related Intellectual Property Rights Agreement (TRIPS): A Case Study of Basmati Rice Exports. Journal of Agricultural and Food Industrial Organization, 9(4), 1-19.

Pauwelyn, J. (2010). The Dog That Barked But Didn’t Bite: 15 Years of Intellectual Property Disputes at the WTO. Journal of International Dispute Settlement, 1(2), 389-429. http://dx.doi.org/10.1093/jnlids/idq001

Schmidt, C. (2010). Refusal to License Intellectual Property Rights as Abuse of Dominance. Frankfurt a.M.: Lang.

Stigler, G. J. (1961). The Economics of Information. Journal of Political Economy, 69(3), 213-225. http://dx.doi.org/10.1086/258464

Streit, M. E., \& Wegner, G. (1989). Information, échangeetcatallaxie. Journal des économisteset des étudeshumaines, 1(1), 3-24.

United States. (2012). Section 110(5) of the US Copyright Act - Status report by the United States - Addendum (WT/DS160/24/Add.85) - Official document of the World Trade Organization.

Watal, J. (2011). From Punta Del Este to Doha and Beyond: Lessons from the TRIPS Negotiating Processes. Retrieved from http://ssrn.com/abstract $=1973177$

Watt, R. (2004). The Past and the Future of the Economics of Copyright. Review of Economic Research on Copyright Issues, 1(1), 151-171.

WTO. (2005). Issues Related to the Extension of the Protection of Geographical Indications Provided for in Article 23 of the TRIPS Agreement to Products other than Wines and Spirits, Compilation of Issues Raised 
and Views Expressed, Note by the Secretariat (WT/GC/W/546) - Official Document of the World Trade Organization, 18.05.2005.

WTO. (2011). Council for Trade-Related Aspects of Intellectual Property Rights - Report on the Implementation of Article 66.2 of the TRIPS Agreement - United States - Addendum, IP/C/W/558/Add.6.

WTO Annual Reports. Different years.

Yoon, K. (2002). The Optimal Level of Copyright Protection. Information Economics and Policy, 14(3), 327-348. http://dx.doi.org/10.1016/S0167-6245(01)00062-2

\section{Notes}

Note 1. On theories of trade of information including critical assessments of marginal calculation approaches to information trade Stigler (1961), Streit \& Wegner (1989) and Kirzner (1992).

Note 2. This is the dominating approach when it comes to modelling copyrights and their effects. See the excellent literature review by Belleflamme \& Peitz (2012).

Note 3. In line with that, songs at discount prices tend to rise in permanently renewed music charts (like itunes or amazon download track charts) as long as they are discounted and some 'official' music charts (like in Germany) even account for this by ordering according to revenues and not 'just' according to quantities.

Note 4. See Schmidt (2010: 88) for a comparable reasoning for detective stories books.

Note 5. See for the following the WTO Annual Reports, different years.

Note 6. For more general discussions of geographical indications as intellectual property see, inter alia, Ilbert \& Petit (2009); Mulik \& Crespi (2009); Kireeva \& O’Connor (2010).

Note 7. In this case, the term 'unfair competition' explicitly relates to the WIPO related Paris Convention (in the 1967 version), where Art. 10bis defines unfair competition as practices 'contrary to honest practices in industrial or commercial matters'. The article exemplarily cites false allegations, discrediting competitors as well as misleading and confusing information about competitors.

Note 8. See also http://www.wto.org/english/tratop_e/dispu_e/cases_e/ds362_e.htm .

Note 9. On the economics of counterfeited goods see the seminal articles by Grossman \& Shapiro (1988a, 1988b).

Note 10. See also http://docsonline.wto.org/GEN_highLightParent.asp?qu=\%28\%40meta $\% 5$ FSymbol+WT\%FC DS160\%FC\%2A\%29\&doc=D\%3A\%2FDDFDOCUMENTS\%2FT\%2FWT\%2FDS\%2F160\%2D24A85\%2EDO C\%2EHTM (accessed: 23.01.2012) and http://www.wto.org/english/tratop_e/dispu_e/cases_e/ds160_e.htm

Note 11. Russia eventually became a WTO member state on the 22nd of August, 2012.

Note 12. This might be different with patents, in particular in the pharmaceutical sector. See e.g. Henry \& Stiglitz (2010).

Note 13. See again the excellent survey by Belleflamme \& Peitz (2012) and their comprehensive references to the literature.

Note 14. Both acts are initiatives in discussion and not yet set into force.

Note 15. Besides these regulations, the new laws would expand the criminal regulations and include the streaming of copyright materials.

Note 16. There may also be a conflict with commitments in the context of the World Intellectual Property Organization (WIPO). Since 1998, the field of intellectual property rights in the US is regulated by the Digital Millennium Copyright Act (DMCA) which came into force in order to fulfil the responsibilities of the US towards two treaties of WIPO, namely the Copyright Treaty and the Performances and Phonograms Treaty.

Note 17. In addition, worries are voiced concerning fundamental principles of the rule of law, the protection of privacy as well as the protection of free speech and diversity of opinions. They are however not discussed in our context. 